\section{Cellular Physiology and Biochemistry}

Published online: March 17, 2016

Accepted: February 10, 2016

This article is licensed under the Creative Commons Attribution-NonCommercial-NoDerivatives 4.0 International License (CC BY-NC-ND) (http://www.karger.com/Services/OpenAccessLicense). Usage and distribution for commercial purposes as well as any distribution of modified material requires written permission.

Original Paper

\title{
Leptin as a Potential Regulator of FGF21
}

\author{
Mohamed Asrih ${ }^{a} \quad$ Christelle Veyrat-Durebex ${ }^{b}$ Anne-Laure Poher ${ }^{b}$ \\ Jacqueline Lyautey ${ }^{b} \quad$ Françoise Rohner-Jeanrenaud $^{\mathrm{b}} \quad$ François R. Jornayvaz $^{\mathrm{a}}$ \\ aService of Endocrinology, Diabetes and Metabolism, Lausanne University Hospital, Lausanne, \\ bLaboratory of Metabolism, Department of Internal Medicine Specialties, Faculty of Medicine, \\ University of Geneva, Geneva, Switzerland
}

\author{
Key Words \\ FGF21 • Leptin • Insulin resistance • Obesity
}

\begin{abstract}
Background/Aims: Fibroblast growth factor 21 (FGF21), a potent metabolic regulator, has been shown to improve insulin sensitivity in animal models of insulin resistance. Several studies have focused on identifying mediators of FGF21 effects. However, the identification of factors involved in FGF21 regulation is far from complete. As leptin is a potent metabolic modulator as well, we aimed at characterizing whether leptin may regulate FGF21. Methods: We investigated a potential regulation of FGF21 by leptin in vivo in Wistar rats and in vitro using human derived hepatocarcinoma HepG2 cells. This model was chosen as the liver is considered the main FGF21 expression site. Results: We found that leptin injections increased plasma FGF21 levels in adult Wistar rats. This was confirmed in vitro, as leptin increased FGF21 expression in HepG2 cells. We also showed that the leptin effect on FGF21 expression was mediated by STAT3 activation in HepG2 cells. Conclusion: New findings regarding a leptinSTAT3-FGF21 axis were provided in this study, although investigating the exact mechanisms linking leptin and FGF21 are still needed. These results are of great interest in the context of identifying potential new clinical approaches to treat metabolic diseases associated with insulin resistance, such as obesity and type 2 diabetes.

\section{Introduction}

Fibroblast growth factor 21 (FGF21) is a potent metabolic regulator, predominantly expressed in the liver and white adipose tissue, but also in skeletal muscle and pancreas [1, 2]. Pharmacological doses of FGF21 have been shown to exert notable anti-diabetic effects. In particular, FGF21 improves glucose tolerance and insulin sensitivity, and reduces plasma and hepatic triglycerides in ob/ob, db/db, and wild-type mice fed a high-fat diet [3-6]. It also protects against high glucose induced cellular damage in endothelial cells, thus potentially promoting vascular health in diabetes [7]. Several studies focused on the identification

M. Asrih and C. Veyrat-Durebex contributed equally.

François Jornayvaz, MD

Service of Endocrinology, Diabetes and Metabolism, Lausanne University Hospital, Mont-Paisible 18, 1011 Lausanne, (Switzerland)

Tel.+41213140601, Fax +41213140630, E-Mail Francois.Jornayvaz@chuv.ch 


\section{Cellular Physiology Cell Physiol Biochem 2016;38:1218-1225

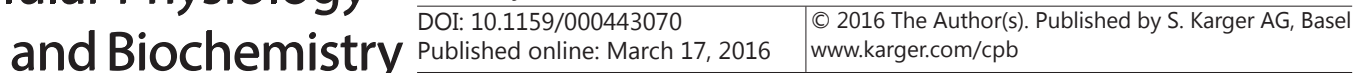 \\ Asrih et al.: A Leptin-FGF21 Crosstalk}

of potential FGF21 mediators [8-10]. Among these mediators, adiponectin was shown to mediate part of FGF21 effects $[8,9]$. Recent evidence also suggests that other factors, such as dual specificity phosphatase 4 or uncoupling protein-1 (UCP1) may mediate FGF21 actions $[11,12]$. With regard to the regulation of FGF21 expression, very limited information is available as yet [13]. Interestingly, FGF21 expression was shown to be under the control of the stress responsive transcription factor, Signal Transducers and Activators of Transcription 3 (STAT3) [14], which is also known to mediate leptin effects [15]. Subsequently, other studies demonstrated that FGF21 is modulated by key metabolic transcription factors such as PPAR $\alpha$ and PPAR $\gamma$ [16-18] which are also induced by leptin [19]. Leptin is also known to promote metabolic health by notably increasing fat oxidation in muscle cells [20] and decreasing inflammation [21]. In the present study, we first investigated whether leptin may regulate FGF21 expression in vivo in Wistar rats. Since FGF21 is predominantly produced by the liver [22], potential leptin effects on FGF21 were also investigated in vitro, in human derived hepatocarcinoma HepG2 cells, a cell line known to produce FGF21 although at very low concentrations under basal conditions [23]. This allowed us to investigate the potential signaling pathways involved in the regulation of FGF21 by leptin.

\section{Materials and Methods}

\section{Animals}

All procedures were performed in accordance with and approved by the Institutional Ethical Committee of Animal Care in Geneva and Cantonal Veterinary Office. Four month-old male Wistar rats were obtained from Charles River (L'Arbresle, France). They were housed under controlled temperature $\left(22^{\circ} \mathrm{C}\right)$ and lighting (lights on: 7 AM to $7 \mathrm{PM}$ ) with free access to water and food (standard diet, laboratory diet RM3, SDS, Essex, UK). To test the effect of leptin on FGF21 secretion, a cohort of rats was euthanized 30 minutes after a single intraperitoneal injection of human recombinant leptin ( $2 \mathrm{mg} / \mathrm{kg}$ ) (PeproTech, Rocky Hill, NJ) or vehicle (saline). This leptin dose was chosen because previous experiments were performed in similar conditions with reliable results. Notably, this dose of leptin was able to decrease food intake in Wistar rats, confirming a response to leptin, which was not the case with lower doses of leptin [24]. Blood and tissues were sampled and stored at $-80^{\circ} \mathrm{C}$ for further analysis.

\section{Plasma measurements}

A commercial ELISA kit was used for the measurement of plasma FGF21 (R\&D systems Europe Ltd, Oxon, UK).

\section{Cell culture}

Human derived hepatocarcinoma HepG2 cells (American Type Culture Collection, Manassas, VA) were cultured in Dulbecco modified Eagle medium (Gibco®, Life Technologies, Zug, Switzerland) supplemented with $10 \%$ fetal bovine serum (FBS, Sigma-Aldrich, Buchs, Switzerland), 1\% (v/v) penicillin streptomycin (Sigma-Aldrich,) at $37{ }^{\circ} \mathrm{C}$ with $5 \% \mathrm{CO}_{2}$. Equivalent numbers of HepG2 cells starved in DMEM basal serumfree media were treated with $200 \mathrm{ng} / \mathrm{mL}$ recombinant leptin (R\&D Systems, Abingdon, UK), PBS (control group), and/or a STAT3 inhibitor $(10 \mu \mathrm{mol} / \mathrm{L})$ (Stattic, Sigma-Aldrich) for $1 \mathrm{~h}$.

\section{Reverse Transcription-Polymerase Chain Reaction (RT-PCR)}

Total RNA from HepG2 cells was extracted using a single-step extraction with Trizol reagent (SigmaAldrich). RNA integrity was assessed by electrophoresis on a $1 \%$ agarose gel and concentration was determined by spectrophotometry. A quantity of $1 \mu \mathrm{g}$ of total RNA was used for RT, using a commercial kit (Takara Bio Europe, St Germain-en-Laye, France). For quantitative PCR, amplification of genes was performed from $50 \mathrm{ng}$ cDNA using the SYBR® green PCR Master Mix (Roche, Rotkreuz, France) and a StepOne $^{\mathrm{TM}}$ Real-Time PCR system (Life Technologies), as previously described [25]. Oligonucleotides were used at $300 \mathrm{nmol} / \mathrm{L}$ and results were normalized to the expression levels of housekeeping genes (Table 1). 


\section{Cellular Physiology Cell Physiol Biochem 2016;38:1218-1225 \begin{tabular}{ll|l} 
and Biochemistry & $\begin{array}{l}\text { DOI: 10.1159/000443070 } \\
\text { Published online: March 17, } 2016\end{array}$ & $\begin{array}{l}\text { C } 2016 \text { The Author(s). Published by S. Karger AG, Basel } \\
\text { www.karger.com/cpb }\end{array}$
\end{tabular} \\ Asrih et al.: A Leptin-FGF21 Crosstalk}

Table 1. Sequences of oligonucleotides used

\begin{tabular}{|c|c|c|c|}
\hline Name & $\begin{array}{c}\text { Gene } \\
\text { symbol }\end{array}$ & Position & Primer \\
\hline \multirow[t]{2}{*}{ Rat Fibroblast growth factor 21} & $m F g f 21$ & Forward & CTGGGGGTCTACCAAGCATA \\
\hline & & Reverse & CACCCAGGATTTGAATGACC \\
\hline \multirow[t]{2}{*}{ Rat Peptidylprolyl isomerase A (also known as Cyclophilin A) } & mPpia & Forward & GGCTCCGTCGTCTTCCTTTT \\
\hline & & Reverse & ACTCGTCCTACAGATTCATCTCC \\
\hline \multirow[t]{2}{*}{ Human Peroxisome proliferator-activated receptor- alpha } & hPpara & Forward & GGGATCAGCTCCGTGGATCT \\
\hline & & Reverse & TGCACTTTGGTACTCTTGAAGTT \\
\hline \multirow[t]{2}{*}{ Human Suppressor of cytokine signaling 3} & hSOCS3 & Forward & CCTGCGCCTCAAGACCTTC \\
\hline & & Reverse & GTCACTGCGCTCCAGTAGAA \\
\hline \multirow[t]{2}{*}{ Human Fibroblast growth factor 21} & $h F g f 21$ & Forward & GCCTTGAAGCCGGGAGTTATT \\
\hline & & Reverse & GTGGAGCGATCCATACAGGG \\
\hline \multirow[t]{2}{*}{ Human Eukaryotic translation elongation factor 1 Alpha 1} & hEef1a1 & Forward & AGCAAAAATGACCCACCAATG \\
\hline & & Reverse & GGCCTGGATGGTTCAGGATA \\
\hline
\end{tabular}

Western blot

HepG2 cells lysates were prepared in RIPA buffer $(150 \mathrm{mmol} / \mathrm{L} \mathrm{NaCl}, 1 \%$ (v/v) Triton X-100, 0.1\% (w/v) SDS, $0.5 \%(\mathrm{w} / \mathrm{v}$ ) Na deoxycholate, $50 \mathrm{mM}$ Tris- $\mathrm{HCl}$ ) with phosphatase and protease inhibitors (Halt protease and phosphatase inhibitor cocktail, Pierce, Lausanne, Switzerland) as previously described [26]. Samples were resolved on a 4-12\% Bis-Tris gel and transferred onto polyvinylidene difluoride membranes. Thereafter, proteins were detected using the following antibodies: anti-pSTAT3 (1:2000, Cell signaling, Allschwil, Switzerland), anti-STAT3 (1:2000, Cell signaling), anti-PPAR $\alpha$ (1:2000, Cell signaling) and tubulin (1:4000, Sigma-Aldrich). The bands were visualized by chemiluminescence (Supersignal West Dura substrate, Pierce) on a detection system (GE Healthcare Europe GmbH, Glattbrugg, Switzerland). Densitometric analysis of chemiluminescent signals captured on camera was performed using the Image J software (National Institutes of Health).

Statistical analyses

Results are expressed as Mean \pm SEM. Statistical calculations were carried out with GraphPad Prism 6 (GraphPad Prism, La Jolla, CA). Statistical significance was established at $\mathrm{p}<0.05$ and determined by unpaired Student's $t$-test or one-way ANOVA.

\section{Results}

Leptin increases plasma FGF21 levels in rats

To study the link between leptin and FGF21, adult male Wistar rats were challenged with an intraperitoneal leptin injection ( $2 \mathrm{mg} / \mathrm{kg}$ ). Plasma FGF21 levels were then evaluated 30 minutes later. Leptin treatment significantly increased plasma FGF21 levels compared to the injection of vehicle (saline), confirming a stimulatory effect of leptin on FGF21 release in this model (Fig. 1). The mRNA expression of Fgf 21 was thereafter evaluated in different tissues. The liver was the tissue predominantly expressing Fgf21, compared to brown (BAT) and inguinal white (WATi) adipose tissue (Fig. 2). However, under our experimental conditions (i.e. 30 minutes after injection), leptin was unable to increase Fgf21 mRNA levels in the liver or in the other tissues (Fig. 2). This suggests a potential time-dependant effect, or an effect of leptin on FGF21 release rather than expression.

\section{Leptin induces Fgf21 expression in HepG2 cells}

To strengthen our in vivo results, we used an in vitro model, focusing on the liver, which is considered the main site of FGF21 production. HepG2 cells were therefore chosen and treated for $1 \mathrm{~h}$ with leptin $(200 \mathrm{ng} / \mathrm{mL})$. Leptin treatment enhanced Fgf21 expression under these experimental conditions (Fig. 3A). Interestingly, an almost significant ( $p=0.07$ ) stimulation of the mRNA expression of Socs3, a direct target of STAT3, was observed (Fig. 3A). As leptin is known to promote activation of STAT3 [27], we assessed whether the leptininduced increase in Fgf21 expression could be mediated by the STAT3 signaling pathway. 


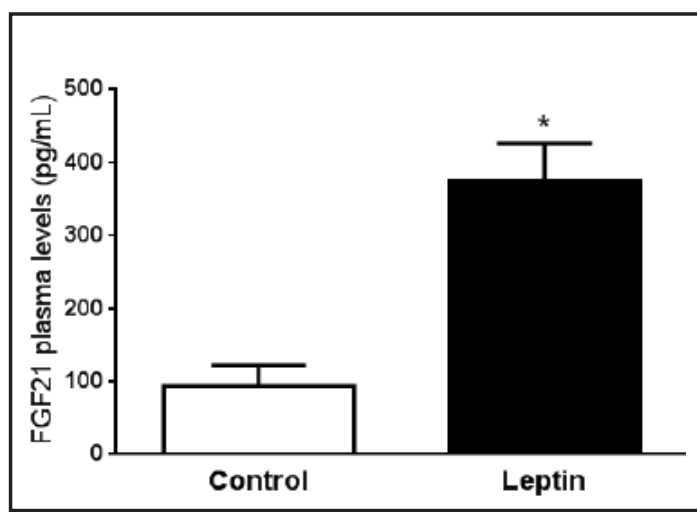

Fig. 1. Leptin increases plasma FGF21 levels in Wistar rats. Plasma FGF21 levels in control (saline) or leptin-treated (2 mg/kg, i.p.) Wistar rats. Mean \pm SEM. *p<0.05 using Student's $t$-test.

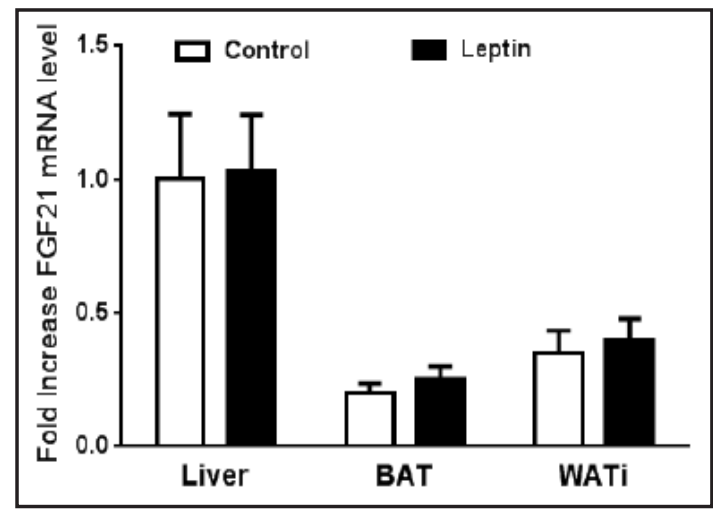

Fig. 2. Acute leptin treatment does not affect Fgf21 mRNA levels in the liver, brown adipose tissue (BAT), or inguinal white adipose tissue (WATi) of Wistar rats. mRNA expression of $F g f 21$ in control (saline) or leptin-treated ( $2 \mathrm{mg} / \mathrm{kg}$, i.p.) Wistar rats. Mean \pm SEM.
Fig. 3. Leptin regulation of FGF21 in HepG2 cells. A) mRNA expression of Fgf21 and Socs3 in untreated (Control) or leptin-treated (Leptin, 200 ng/mL) HepG2 cells. B) Quantification and representative Western blots of phosphorylated STAT3 (pSTAT3) and STAT3 in the presence (Leptin + Stattic, $1 \mathrm{~h}$ ) or absence (Leptin) of the STAT3 inhibitor, Stattic, compared to untreated cells (C). C) mRNA expression of Fgf21 in untreated (C) or leptintreated HepG2 cells in the presence, or the absence of Stattic. Mean \pm SEM of $n=4$ experiments for qPCR using Student's $t$-test or one-way ANOVA. ${ }^{*} \mathrm{p}<0.05$ leptin versus control, $\# \mathrm{p}<0.05$ leptin versus control, $\S \mathrm{p}<0.05$ leptin + stattic versus leptin.

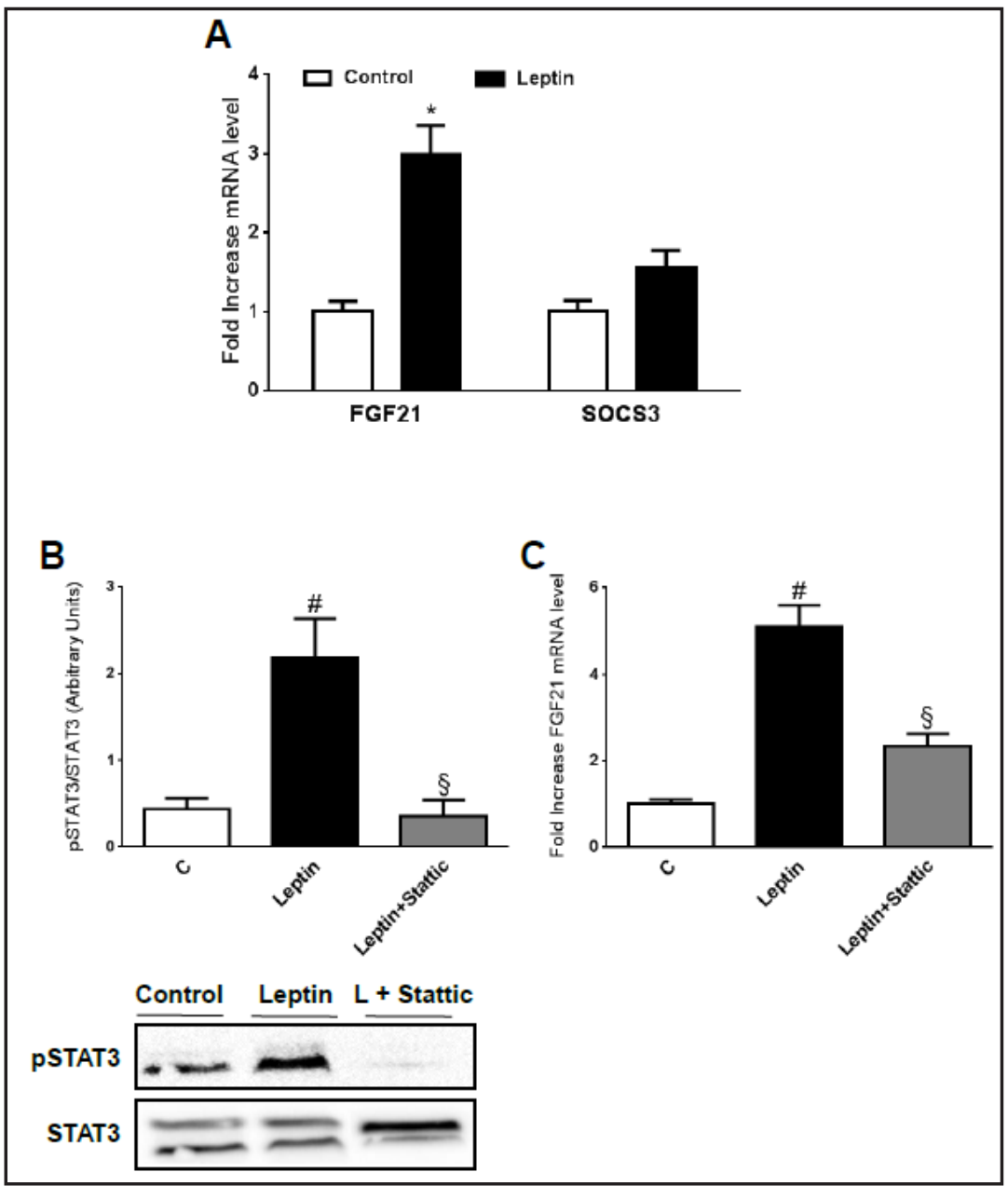

To this end, HepG2 cells were treated with leptin $(200 \mathrm{ng} / \mathrm{mL})$ in the presence, or in the absence, of a STAT3 inhibitor (Stattic, $10 \mu \mathrm{mol} / \mathrm{L}, 1 \mathrm{~h}$ ). As expected, leptin increased STAT3 phosphorylation whereas the presence of the STAT3 inhibitor in the medium resulted in a significant inhibition of phosphorylation (Fig. 3B). Importantly, the presence of the 


\section{Cellular Physiology Cell Physiol Biochem 2016;38:1218-1225 \begin{tabular}{l|l} 
and Biochemistry Published online: March 17, 2016 & $\begin{array}{l}\text { C } 2016 \text { The Author(s). Published by S. Karger AG, Basel } \\
\text { www.karger.com/cpb }\end{array}$
\end{tabular} Asrih et al.: A Leptin-FGF21 Crosstalk}

Fig. 4. Effect of leptin on PPAR $\alpha$ in HepG2 cells. A) mRNA expression of Ppara; B) Quantification and representative Western blots of PPAR $\alpha$ and Tubulin in untreated (Control) or leptin-treated (Leptin) HepG2 cells. Mean \pm SEM of $n=4$ experiments for qPCR. * ${ }^{*}<0.05$ using Student's $t$-test.

inhibitor also prevented the leptin-induced Fgf21 expression (Fig. 3C), confirming that the effect of leptin on FGF21 is mediated by STAT3 activation.

As PPAR $\alpha$ is also known to regulate $F g f 21$ gene expression [28], we then tested whether leptin could stimulate Fgf21 expression through the PPAR $\alpha$ pathway. We observed that $1 \mathrm{~h}$ of leptin treatment increased Ppara mRNA expression in HepG2 cells (Fig. 4A). However, as determined using Western blotting, PPAR $\alpha$ protein levels tended to be increased by leptin (Fig. 4B), but this was not significant $(\mathrm{p}=0.1)$. These results could potentially suggest a post-transcriptional regulation of PPAR $\alpha$ by leptin, which will require further investigations in future

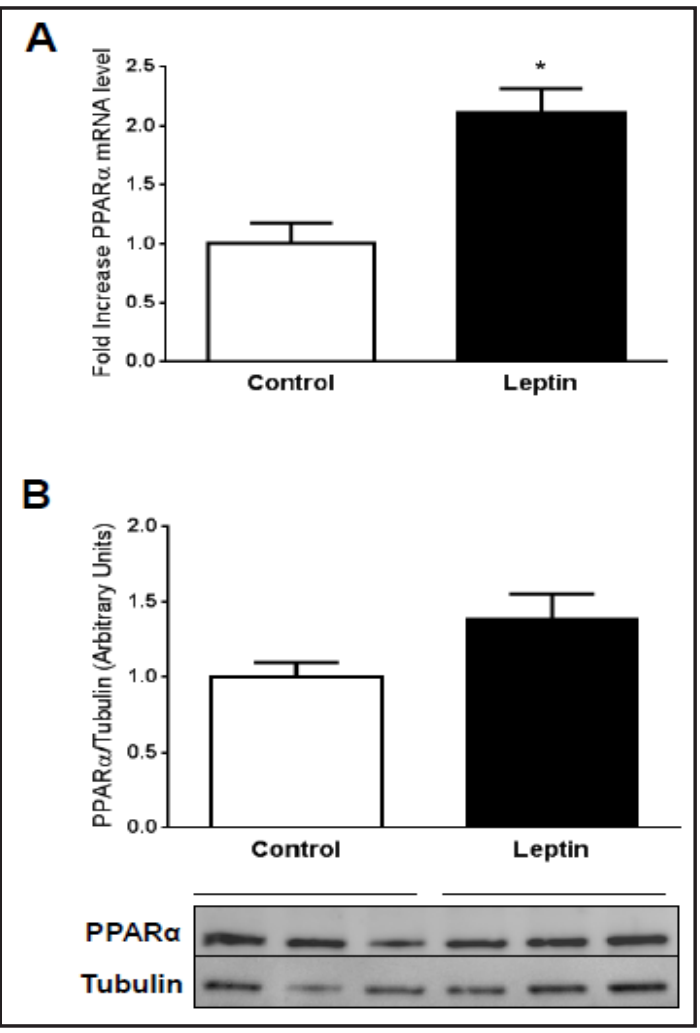
studies. Alternatively, it is conceivable that $1 \mathrm{~h}$ of leptin treatment was not long enough to observe any significant difference in protein synthesis.

\section{Discussion}

FGF21, a potent metabolic regulator, has been shown to improve glucose and lipid metabolism, as well as to reduce body weight and adipose tissue mass [3-6, 29-31]. These favorable effects seem to be mainly mediated by white adipose tissue, since lack of FGF receptor 1 (FGFR1) in this tissue abolishes the metabolic actions of FGF21 [32, 33]. FGF21 has also been shown to improve insulin sensitivity and hepatic steatosis in high-fat fed mice [4]. On the opposite, mice lacking $F g f 21$ develop hepatic steatosis and hepatic insulin resistance when fed a high-fat ketogenic diet [23]. Several studies focused on the identification of FGF21 mediators [8-10]. Although adiponectin was described as one of the main mediators of FGF21 action, recent evidence suggests that other factors may be involved as well $[11,12]$. Nevertheless, limited information is available regarding the regulation of Fgf21 expression itself.

Here, we report that leptin is a potential new regulator of FGF21. Indeed, we observed that leptin administration acutely increased plasma FGF21 plasma levels in Wistar rats. This likely resulted from a release of FGF21 from the liver, as suggested by the literature [3], although we could not find any difference in Fgf21 expression in the liver or other tissues. However, skeletal muscle has also been suggested as a site of FGF21 production $[34,35]$ and could have revealed increased Fgf21 expression after leptin administration. However, we did not sample any skeletal muscle in our rats. Nonetheless, it is also possible that timing of tissue harvesting (30 minutes in our in vivo experimental conditions) might have accounted for our findings, suggesting that a faster or slower regulation by leptin on tissue Fgf21 expression might occur. The rapid effect of leptin on FGF21 levels however suggests an effect on secretion. Notably, leptin is known to rapidly (within minutes) and directly inhibit insulin secretion by the pancreas [36]. FGF21 is also rapidly (within 15 minutes) expressed by the pancreas after acute pancreatic injury [37]. Therefore, it could be hypothesized that leptin 


\section{Cellular Physiology Cell Physiol Biochem 2016;38:1218-1225 \begin{tabular}{l|l} 
and Biochemistry Published online: March 17, 2016 & $\begin{array}{l}\text { DOI: 10.1159/000443070 } 2016 \text { The Author(s). Published by S. Karger AG, Basel } \\
\text { www.karger.com/cpb }\end{array}$
\end{tabular} \\ Asrih et al.: A Leptin-FGF21 Crosstalk}

might stimulate rapid pancreatic FGF21 expression and release. Unfortunately, we did not sample the pancreas of our leptin-treated rats. Altogether, these considerations therefore warrant further in vivo research.

Nevertheless, our in vitro results obtained in HepG2 cells clearly show an effect of leptin on Fgf21 expression. Moreover, we show that this leptin effect is mediated by STAT3 activation, as not only STAT3 phosphorylation, but also Fgf21 expression, were prevented in the presence of a STAT3 inhibitor. These findings therefore provide a potential signaling pathway by which leptin regulates FGF21. A possible involvement of PPAR $\alpha$ activation remains to be elucidated in future studies, but is likely to play a role in the crosstalk between leptin and FGF21. As in vitro studies do not take into account potential interactions between tissues, for example between liver and white adipose tissue, further studies are required in vivo to better clarify the potential regulation of FGF21 by leptin.

The role of FGF21 as a mediator of leptin action may be of significant relevance in various metabolic regulation processes. As an example, impaired leptin signaling in the liver, known to promote hepatic steatosis [38], may be due to impaired hepatic Fgf21 expression. Nevertheless, the peripheral effect of leptin is a subject of debate. Notably, mice with specific leptin receptor deletion in the liver do not recapitulate the metabolic phenotype of $d b / d b$ mice. Indeed, metabolic effects of leptin and notably its weight-reducing effects are more likely to be the results of the central leptin action on the brain [39]. However, obesity is a leptin resistance state [40]. Moreover, FGF21 levels are also increased in obesity, which also suggest a resistant state $[41,42]$. Therefore, it could be speculated that co-administration of leptin and FGF21 could reveal a synergistic effect in obesity to overcome this state of hormonal resistance. This may also be true in other situations of hormone resistance, notably insulin resistance, encountered not only in obesity, but also in conditions associated with the metabolic syndrome, such as type 2 diabetes and nonalcoholic fatty liver disease [43]. These considerations warrant further in vivo studies.

Altogether, our results provide new findings regarding a leptin-STAT3-FGF21 axis that may lead to beneficial metabolic effects. These findings warrant further in vivo work to assess whether leptin-induced FGF21 could improve diseases associated with insulin resistance such as obesity, type 2 diabetes and nonalcoholic fatty liver disease.

\section{Acknowledgments}

This work was supported by the Helmut Horten Foundation, the Novartis Foundation for medical-biological research, the Leenaards Foundation and the Raymond Berger Foundation to FR Jornayvaz and by a grant from the Swiss National Science Foundation (Bern, Switzerland), FNRS: 31003A_134919 and 310030_160290/1 to F. Rohner-Jeanrenaud.

\section{Disclosure Statement}

The authors have nothing to disclose.

\section{References}

1 Murata Y, Konishi M, Itoh N: FGF21 as an Endocrine Regulator in Lipid Metabolism: From Molecular Evolution to Physiology and Pathophysiology. J Nutr Metab 2011;2011:981315.

2 Nishimura T, Nakatake Y, Konishi M, Itoh N: Identification of a novel FGF, FGF-21, preferentially expressed in the liver. Biochim Biophys Acta 2000;1492:203-206.

3 Kharitonenkov A, Shiyanova TL, Koester A, Ford AM, Micanovic R, Galbreath EJ, Sandusky GE, Hammond LJ, Moyers JS, Owens RA, Gromada J, Brozinick JT, Hawkins ED, Wroblewski VJ, Li DS, Mehrbod F, Jaskunas SR, Shanafelt AB: FGF-21 as a novel metabolic regulator. J Clin Invest 2005;115:1627-1635.

4 Camporez JP, Jornayvaz FR, Petersen MC, Pesta D, Guigni BA, Serr J, Zhang D, Kahn M, Samuel VT, Jurczak MJ, Shulman GI: Cellular mechanisms by which FGF21 improves insulin sensitivity in male mice. Endocrinology 2013;154:3099-3109. 


\section{Cellular Physiology Cell Physiol Biochem 2016;38:1218-1225

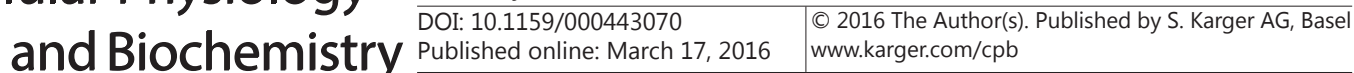 \\ Asrih et al.: A Leptin-FGF21 Crosstalk}

5 Coskun T, Bina HA, Schneider MA, Dunbar JD, Hu CC, Chen Y, Moller DE, Kharitonenkov A: Fibroblast growth factor 21 corrects obesity in mice. Endocrinology 2008;149:6018-6027.

6 Xu J, Lloyd DJ, Hale C, Stanislaus S, Chen M, Sivits G, Vonderfecht S, Hecht R, Li YS, Lindberg RA, Chen JL, Jung DY, Zhang Z, Ko HJ, Kim JK, Veniant MM: Fibroblast growth factor 21 reverses hepatic steatosis, increases energy expenditure, and improves insulin sensitivity in diet-induced obese mice. Diabetes 2009;58:250-259.

7 Wang XM, Song SS, Xiao H, Gao P, Li XJ, Si LY: Fibroblast growth factor 21 protects against high glucose induced cellular damage and dysfunction of endothelial nitric-oxide synthase in endothelial cells. Cell Physiol Biochem 2014;34:658-671.

8 Holland WL, Adams AC, Brozinick JT, Bui HH, Miyauchi Y, Kusminski CM, Bauer SM, Wade M, Singhal E, Cheng CC, Volk K, Kuo MS, Gordillo R, Kharitonenkov A, Scherer PE: An FGF21-adiponectin-ceramide axis controls energy expenditure and insulin action in mice. Cell Metab 2013;17:790-797.

9 Lin Z, Tian H, Lam KS, Lin S, Hoo RC, Konishi M, Itoh N, Wang Y, Bornstein SR, Xu A, Li X: Adiponectin mediates the metabolic effects of FGF21 on glucose homeostasis and insulin sensitivity in mice. Cell Metab 2013;17:779-789.

10 Veniant MM, Hale C, Helmering J, Chen MM, Stanislaus S, Busby J, Vonderfecht S, Xu J, Lloyd DJ: FGF21 promotes metabolic homeostasis via white adipose and leptin in mice. PLoS One 2012;7:e40164.

11 Muise ES, Souza S, Chi A, Tan Y, Zhao X, Liu F, Dallas-Yang Q, Wu M, Sarr T, Zhu L, Guo H, Li Z, Li W, Hu W, Jiang G, Paweletz CP, Hendrickson RC, Thompson JR, Mu J, Berger JP, Mehmet H: Downstream signaling pathways in mouse adipose tissues following acute in vivo administration of fibroblast growth factor 21. PLoS One 2013;8:e73011.

12 Markan KR, Naber MC, Ameka MK, Anderegg MD, Mangelsdorf DJ, Kliewer SA, Mohammadi M, Potthoff MJ: Circulating FGF21 is liver derived and enhances glucose uptake during refeeding and overfeeding. Diabetes 2014;63:4057-4063.

13 Lundasen T, Hunt MC, Nilsson LM, Sanyal S, Angelin B, Alexson SE, Rudling M: PPARalpha is a key regulator of hepatic FGF21. Biochem Biophys Res Commun 2007;360:437-440.

14 Yang C, Lu W, Lin T, You P, Ye M, Huang Y, Jiang X, Wang C, Wang F, Lee MH, Yeung SC, Johnson RL, Wei C, Tsai RY, Frazier ML, McKeehan WL, Luo Y: Activation of Liver FGF21 in hepatocarcinogenesis and during hepatic stress. BMC Gastroenterol 2013;13:67.

15 Luo W, Bodary PF, Shen Y, Wickenheiser KJ, Ohman MK, Guo C, Bahrou KL, Myers MG, Jr., Eitzman DT: Leptin receptor-induced STAT3-independent signaling pathways are protective against atherosclerosis in a murine model of obesity and hyperlipidemia. Atherosclerosis 2011;214:81-85.

16 Muise ES, Azzolina B, Kuo DW, El-Sherbeini M, Tan Y, Yuan X, Mu J, Thompson JR, Berger JP, Wong KK: Adipose fibroblast growth factor 21 is up-regulated by peroxisome proliferator-activated receptor gamma and altered metabolic states. Mol Pharmacol 2008;74:403-412.

17 Mraz M, Bartlova M, Lacinova Z, Michalsky D, Kasalicky M, Haluzikova D, Matoulek M, Dostalova I, Humenanska V, Haluzik M: Serum concentrations and tissue expression of a novel endocrine regulator fibroblast growth factor-21 in patients with type 2 diabetes and obesity. Clin Endocrinol (Oxf) 2009;71:369-375.

18 Galman C, Lundasen T, Kharitonenkov A, Bina HA, Eriksson M, Hafstrom I, Dahlin M, Amark P, Angelin B, Rudling M: The circulating metabolic regulator FGF21 is induced by prolonged fasting and PPARalpha activation in man. Cell Metab 2008;8:169-174.

19 Qian H, Hausman GJ, Compton MM, Azain MJ, Hartzell DL, Baile CA: Leptin regulation of peroxisome proliferator-activated receptor-gamma, tumor necrosis factor, and uncoupling protein-2 expression in adipose tissues. Biochem Biophys Res Commun 1998;246:660-667.

20 Nozhenko Y, Rodriguez AM, Palou A: Leptin rapidly induces the expression of metabolic and myokine genes in C2C12 muscle cells to regulate nutrient partition and oxidation. Cell Physiol Biochem 2015;35:92-103.

21 Landgraf MA, Silva RC, Correa-Costa M, Hiyane MI, Carvalho MH, Landgraf RG, Camara NO: Leptin downregulates LPS-induced lung injury: role of corticosterone and insulin. Cell Physiol Biochem 2014;33:835-846.

22 Diaz-Delfin J, Hondares E, Iglesias R, Giralt M, Caelles C, Villarroya F: TNF-alpha represses beta-Klotho expression and impairs FGF21 action in adipose cells: involvement of JNK1 in the FGF21 pathway. Endocrinology 2012;153:4238-4245. 


\section{Cellular Physiology Cell Physiol Biochem 2016;38:1218-1225 \begin{tabular}{l|l} 
and Biochemistry Published online: March 17, 2016 & $\begin{array}{l}\text { C) 2016 The Author(s). Published by S. Karger AG, Basel } \\
\text { www.karger.com/cpb }\end{array}$ \\
\hline
\end{tabular} \\ Asrih et al.: A Leptin-FGF21 Crosstalk}

23 Camporez JP, Asrih M, Zhang D, Kahn M, Samuel VT, Jurczak MJ, Jornayvaz FR: Hepatic insulin resistance and increased hepatic glucose production in mice lacking Fgf21. J Endocrinol 2015;226:207-217.

24 Veyrat-Durebex C, Poher AL, Caillon A, Somm E, Vallet P, Charnay Y, Rohner-Jeanrenaud F: Improved leptin sensitivity as a potential candidate responsible for the spontaneous food restriction of the Lou/C rat. PLoS One 2013;8:e73452.

25 Asrih M, Altirriba J, Rohner-Jeanrenaud F, Jornayvaz FR: Ketogenic Diet Impairs FGF21 Signaling and Promotes Differential Inflammatory Responses in the Liver and White Adipose Tissue. PLoS One 2015;10:e0126364.

26 Asrih M, Montessuit C, Philippe J, Jornayvaz FR: Free Fatty Acids Impair FGF21 Action in HepG2 Cells. Cell Physiol Biochem 2015;37:1767-1778.

27 Jiang L, Li Z, Rui L: Leptin stimulates both JAK2-dependent and JAK2-independent signaling pathways. J Biol Chem 2008;283:28066-28073.

28 Vernia S, Cavanagh-Kyros J, Garcia-Haro L, Sabio G, Barrett T, Jung DY, Kim JK, Xu J, Shulha HP, Garber M, Gao G, Davis RJ: The PPARalpha-FGF21 hormone axis contributes to metabolic regulation by the hepatic JNK signaling pathway. Cell Metab 2014;20:512-525.

29 Arner P, Pettersson A, Mitchell PJ, Dunbar JD, Kharitonenkov A, Ryden M: FGF21 attenuates lipolysis in human adipocytes - a possible link to improved insulin sensitivity. FEBS Lett 2008;582:1725-1730.

30 Badman MK, Pissios P, Kennedy AR, Koukos G, Flier JS, Maratos-Flier E: Hepatic fibroblast growth factor 21 is regulated by PPARalpha and is a key mediator of hepatic lipid metabolism in ketotic states. Cell Metab 2007;5:426-437.

31 Wente W, Efanov AM, Brenner M, Kharitonenkov A, Koster A, Sandusky GE, Sewing S, Treinies I, Zitzer H, Gromada J: Fibroblast growth factor-21 improves pancreatic beta-cell function and survival by activation of extracellular signal-regulated kinase 1/2 and Akt signaling pathways. Diabetes 2006;55:2470-2478.

32 Adams AC, Yang C, Coskun T, Cheng CC, Gimeno RE, Luo Y, Kharitonenkov A: The breadth of FGF21's metabolic actions are governed by FGFR1 in adipose tissue. Mol Metab 2012;2:31-37.

33 Woo YC, Xu A, Wang Y, Lam KS: Fibroblast growth factor 21 as an emerging metabolic regulator: clinical perspectives. Clin Endocrinol (Oxf) 2013;78:489-496.

34 Hojman P, Pedersen M, Nielsen AR, Krogh-Madsen R, Yfanti C, Akerstrom T, Nielsen S, Pedersen BK: Fibroblast growth factor-21 is induced in human skeletal muscles by hyperinsulinemia. Diabetes 2009;58:2797-2801.

35 Lindegaard B, Hvid T, Grondahl T, Frosig C, Gerstoft J, Hojman P, Pedersen BK: Expression of fibroblast growth factor-21 in muscle is associated with lipodystrophy, insulin resistance and lipid disturbances in patients with HIV. PLoS One 2013;8:e55632.

36 Kulkarni RN, Wang ZL, Wang RM, Hurley JD, Smith DM, Ghatei MA, Withers DJ, Gardiner JV, Bailey CJ, Bloom SR: Leptin rapidly suppresses insulin release from insulinoma cells, rat and human islets and, in vivo, in mice. J Clin Invest 1997;100:2729-2736.

37 Johnson CL, Weston JY, Chadi SA, Fazio EN, Huff MW, Kharitonenkov A, Koester A, Pin CL: Fibroblast growth factor 21 reduces the severity of cerulein-induced pancreatitis in mice. Gastroenterology 2009;137:17951804.

38 Huynh FK, Neumann UH, Wang Y, Rodrigues B, Kieffer TJ, Covey SD: A role for hepatic leptin signaling in lipid metabolism via altered very low density lipoprotein composition and liver lipase activity in mice. Hepatology 2013;57:543-554.

39 Cohen P, Zhao C, Cai X, Montez JM, Rohani SC, Feinstein P, Mombaerts P, Friedman JM: Selective deletion of leptin receptor in neurons leads to obesity. J Clin Invest 2001;108:1113-1121.

40 Myers MG, Jr., Leibel RL, Seeley RJ, Schwartz MW: Obesity and leptin resistance: distinguishing cause from effect. Trends Endocrinol Metab 2010;21:643-651.

41 Dushay J, Chui PC, Gopalakrishnan GS, Varela-Rey M, Crawley M, Fisher FM, Badman MK, Martinez-Chantar ML, Maratos-Flier E: Increased fibroblast growth factor 21 in obesity and nonalcoholic fatty liver disease. Gastroenterology 2010;139:456-463.

42 Fisher FM, Chui PC, Antonellis PJ, Bina HA, Kharitonenkov A, Flier JS, Maratos-Flier E: Obesity is a fibroblast growth factor 21 (FGF21)-resistant state. Diabetes 2010;59:2781-2789.

43 Asrih M, Jornayvaz FR: Metabolic syndrome and nonalcoholic fatty liver disease: Is insulin resistance the link? Mol Cell Endocrinol 2015;418:55-65. 